\title{
Agglomeration externalities, market structure and employment growth in high-tech industries: Revisiting the evidence
}

Abstract

In this paper we revisit the existing empirical evidence on the effects of various agglomeration externalities and the market structure on employment growth in the high-tech industries of the European Economic Area (EEA). Our study is based on the dynamic panel dataset of two-digit NACE rev 1.1. industries in 285 regions of the European Economic Area for the period 1995-2007. We find that employment growth is negatively related to competition, while localization and urbanization externalities do not seem to affect growth.

\section{Keywords}

Agglomeration externalities • Employment growth • High-tech industries • Market structure

(C) University of Warsaw - Faculty of Geography and Regional Studies

\author{
Andrzej Cieślik', Mahdi Ghodsi² \\ 'Department of Macroeconomics \\ and International Trade Theory, \\ Faculty of Economic Sciences, \\ University of Warsaw \\ Poland \\ email: cieslik@wne.uw.edu.pl \\ ${ }^{2}$ The Vienna Institute for International \\ Economic Studies, Austria \\ email: ghodsi@wiiw.ac.at \\ Received: 17 November 2014 \\ Accepted: 2 June 2015
}

\section{Introduction}

The role of agglomeration externalities as the driving force for technological advancement has long been stressed in the new growth theory literature (Romer, 1986; Lucas, 1988). However, the existing empirical studies do not seem to yield clear-cut evidence of these externalities. For example, in their extensive survey of 67 previous empirical studies, Beaudry and Schiffauerova (2009) were not able to conclude which type of agglomeration externalities enhances growth.

The previous studies focused on the static externalities of which two main types were distinguished: i) urbanization economies in which a firm benefits from overall local urban scale and diversity, and ii) localization economies in which a firm benefits from the presence of other local firms in the same industry (Henderson et al., 1995). In addition to the static externalities, two main types of dynamic externalities were also distinguished: i) Jacobs (1969) urbanization economies which derive from the transfer of knowledge from outside the core industry, and ii) Marshall-Arrow-Romer (MAR) localization economies that concern knowledge spillovers between local firms in the same industry.

In addition to the agglomeration externalities, the role of the market structure in enhancing industry growth has also been studied. According to the MAR hypothesis, local monopoly encourages growth since it restricts the flow of ideas to other firms and allows potential externalities to be internalized by the innovator. However, this view was called into question by Porter (1990) who agrees with the MAR hypothesis on the role of knowledge spillovers but argues that local competition, rather than monopoly, should foster industry growth.

The main goal of this paper is to revisit the evidence on the impact of agglomeration externalities and the market structure on employment growth in 3 high-tech industries in 285 regions of the European Economic Area (EEA) during the period 19952007. The structure of this paper is organized as follows. In the next section, a review of the existing empirical studies on externalities associated with knowledge spillovers is provided. In the subsequent sections we describe the analytical framework, the dataset and the empirical results. The last section concludes with the summary of results and policy guidelines.

\section{Literature Review}

Extensive empirical studies on agglomeration externalities were initially undertaken for the US cities and metropolitan areas. In particular, Glaeser et al. (1992) tested for these externalities using data on the 170 largest U.S. cities during the period 1956-1987. They found that urban diversity and local competition, but not regional specialization, stimulated employment growth. This result was consistent with the Jacobs hypothesis and contradicted the MAR hypothesis. Henderson et al. (1995) used a similar approach to test for agglomeration externalities. Their dataset included 224 Metropolitan Statistical Areas in the U.S. during the period 19701987 and allowed them to distinguish between mature industries and new high-tech industries to find that externalities for both groups of industries were different.

In one of the earliest studies for the European regions, Combes (2000) studied the employment growth in manufacturing industries and service industries in 341 French local areas during the period 1984-1993. He found that, in the manufacturing industries' local total employment density, competition and plant size always reduced local employment growth, while service sectors exhibited negative specialization effects and positive diversity effects. Competition and plant size generally had a negative impact and density a positive one. 
In another study, Blien et al. (2006) considered the impact of specialization and diversification on employment growth in 326 West German NUTS-03 regions during the period 1980-2001. They also distinguished between manufacturing and service industries. Moreover, they corrected for endogeneity and fixed effect problems in their regression using the Generalized Method of Moments (GMM) method. They found a positive and statistically significant sign of the estimated coefficient on the lagged dependent variable which served as a proxy for MAR externalities. Moreover, they found a positive impact of diversification measure on the growth of employment of both groups of industries.

The aforementioned studies focus on single countries and there is still little multi-country evidence. The notable exception is the study by Greunz (2004), who investigated the impact of MAR and Jacobs spillovers on innovation in manufacturing industries in 153 European regions during the period 1997-1998. She used the number of regional patent applications to the European Patent Office as the main dependent variable. She found that both specialization and diversification had a positive impact on firms' innovations. However, her study was limited to the old EU member states.

Another exception is the recent study by Cieślik and Ghodsi (2014), who investigate the impact of specialization, diversification, and competition externalities on the regional growth of employment in the high-tech industries of the European Economic Area (EEA). They found that regional employment growth was positively related to specialization externalities, and negatively to local competition, while diversification had no impact on growth. In this paper we extend the study by Cieślik and Ghodsi (2014) to test empirically for the importance of agglomeration externalities using an alternative measure of specialization. Therefore, this paper can be viewed as an extension of the previous literature on agglomeration externalities for the entire EEA, including both the old and the new EU membes states as well as the EFTA countries.

\section{Analytical Framework and Dataset}

In this section we discuss the empirical framework used to study the effects of agglomeration externalities and the market structure on regional employment growth. Following the seminal study by Glaeser et al. (1992) we define the regional production function for i-th industry in which firms produce output $Y$, using labour $L$ with a technology level $A$ as follows:

$Y_{\text {rit }}=A_{\text {rit }} L_{\text {rit }}^{1-\alpha}$

where $0<\alpha<1$ and $r$ denotes region, i industry, and t time. Given the level of technology, prices, and wages, firms are maximizing their profits given by:

$\pi_{\text {rit }}=p_{i t} A_{\text {rit }} L_{\text {rit }}^{1-\alpha}-w_{\text {rit }} L_{\text {rit }}$

where $p_{i t}$ is the price of the product of the industry $i$ at time $t$ that for simplicity will be normalized to one, and $w_{\text {rit }}$ is the wage rate. The first order condition for profit maximization of the firm is:

$(1-\alpha) A_{\text {rit }} L_{\text {rit }}{ }^{-\alpha}=w_{\text {rit }}$

After taking logs of both sides of equation (3) and some rearrangements, we can express the level of employment as the function of the level of technology and wages:

$\ln L_{\text {rit }}=\left(\frac{1}{\alpha}\right) \ln (1-\alpha)+\left(\frac{1}{\alpha}\right) \ln A_{\text {rit }}-\left(\frac{1}{\alpha}\right) \ln w_{\text {rit }}$
Assuming that $\alpha$ is constant over time and subtracting from equation (4) its one-period-lag, the rate of growth of technology can be written as:

$\ln \left(\frac{L_{\text {rit }}}{L_{\text {rit-1 }}}\right)=\left(\frac{1}{\alpha}\right) \ln \left(\frac{A_{\text {rit }}}{A_{\text {rit }-1}}\right)-\left(\frac{1}{\alpha}\right) \ln \left(\frac{w_{\text {rit }}}{w_{\text {rit-1 }}}\right)$

Thus, regional employment growth in i-th industry is a function of regional growth of technology and wage rate growth. The level of regional technology in the industry can be split into two components: global technology, and local technology:

$A_{\text {rit }}=A_{\text {local }} A_{\text {global }}=A_{\text {rt }} A_{t}$

Consequently, the growth rate of regional technology can be written as:

$\ln \left(\frac{A_{\text {rit }}}{A_{r i t-1}}\right)=\ln \left(\frac{A_{r t}}{A_{r t-1}}\right)+\ln \left(\frac{A_{t}}{A_{t-1}}\right)$

The global component of technology is capturing the exogenous changes in technology that affect both the industry and the whole economy. The regional component of technology is a function of externalities associated with knowledge spillovers in the region:

$\ln \left(\frac{A_{r t}}{A_{r t-1}}\right)=g(S, D, C)$

where S, D, and C are the measures of specialization, diversification, and competition. Substituting equations (8) and (7) into equation (5) we obtain:

$\ln \left(\frac{L_{\text {rit }}}{L_{\text {rit }-1}}\right)=\left(\frac{1}{\alpha}\right) \ln \left(\frac{A_{t}}{A_{t-1}}\right)-\left(\frac{1}{\alpha}\right) \ln \left(\frac{w_{\text {rit }}}{w_{\text {rit-1 }}}\right)+g(S, D, C)$

Equation (9) shows that regional employment growth in i-th industry is a function of wages, global technology changes, regional agglomeration externalities and the market structure. Wage growth should be negatively related to employment growth, since higher wages lower the demand for labour. Growth in the global level of technology positively affects regional employment growth. However, the theory does offer clear predictions concerning the effects of various types of agglomeration externalities and the market structure on employment growth.

According to the MAR hypothesis, $g$ is a positive function of specialization $S$ and a negative function of competition $C$. This suggests that firm concentration in the same industry should increase employment growth while competition should decrease it. According to the Jacobs hypothesis, $g$ is a positive function of both diversification $\mathrm{D}$ and competition $\mathrm{C}$. This means that increased diversity of industries and more competition among firms in the region should enhance employment growth. Hence, the predictions of the MAR and Jacobs hypotheses are in complete opposition. Finally, Porter (1990) agrees with the MAR hypothesis on the positive effect of specialization and agrees with Jacobs on the positive impact of competition. According to the Porter hypothesis, $g$ is a positive function of both specialization $\mathrm{S}$ and competition $\mathrm{C}$. This means that increased specialization and more competition among firms within the industry should positively affect employment growth. Since there is a lack of agreement between the different theories, the impact of various agglomeration externalities and the market structure on employment growth has to be investigated empirically. 
In this study to measure regional firm concentration in the high-tech industries, we use the following index of specialization, which is the fraction of regional employment that the industry represents in the region, relative to the share of employment of the industry nationwide (all regions).

$$
S=\frac{\frac{L_{i, r, t}}{L_{r, t}}}{\frac{L_{i, t}}{L_{t}}}=\frac{\frac{L_{i, r, t}}{\sum_{i=1}^{N} L_{i, r, t}}}{\frac{\sum_{r=1}^{R} L_{i, r, t}}{\sum_{i=1}^{N} \sum_{r=1}^{R} L_{i, r, t}}}
$$

where: $L_{\text {irt }}$ is the total employment for industry $i$ in region $r$ at time $t, \mathrm{~N}$ is the number of all industries in the region and $\mathrm{R}$ is the total number of regions that have this industry. The greater the value of this measure, the higher the geographical concentration of employment.

This form of MAR spillovers can show how specialized a region is in an industry relative to how much that industry was distributed randomly across all regions of the analysis. It reflects both the economic activity of the region in the whole sample and the concentration of industry in the region. This index can control for the situations in which the regional industry is only big because the city is large and it can capture both the intensity and density of interaction among firms. However, higher values of this index can determine a higher specialization of industry in the region relative to other regions' industrial activities.

Various measures of diversification were proposed in the empirical literature. The most commonly used measure of diversification is the Hirschman-Herfindahl index $(\mathrm{HHI})$. This measure was used previously inter alia by Henderson et al. (1995), and Duranton and Puga (2000). This index is defined as the sum of the squares of shares of other industries' employment in the region relative to the total employment of the region, apart from the respective industry in question:

$D_{1}=H H I_{r i t}=\sum_{i^{\prime} \neq i}^{N} S_{r i^{\prime}}^{2}=\sum_{i^{\prime} \neq i}^{N}\left(\frac{L_{r i^{\prime} t}}{\sum_{i^{\prime} \neq i}^{N} L_{r i^{\prime} t}}\right)^{2}$

where $i$ ' denotes all industries in the region other than the respective one under analysis, and definitions of $r, i, t$, and $L$ are the same as before. This measure shows the regional concentration of industries other than the respective one under investigation. The value of this index ranges between $1 / \mathrm{N}$ and 1 , and a higher value of this index shows less diversity in the region. In fact, if all of the economic activities other than the respective industry are agglomerated in one industry, this measure receives the value of 1 .

The alternative measure of diversification is the normalized form of $\mathrm{HHI}$ that controls for regional characteristics of the economic activity among all regions. This measure is defined as:

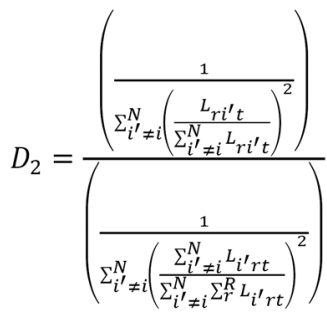

where: i' denotes other industries, and for all other indicators, i, r, $t, N, R$, and $L$, previous definitions hold. Since this is the inverse of normalized $\mathrm{HHI}$, a higher value represents higher diversification of other industries.

Finally, another measure of diversification can be based on the Theil index. This index shows the distribution of industrial activities in the region, which is equal and unique for all industries in the region and is defined as:

$T_{r}=\frac{1}{N_{r}} \sum_{i=1}^{N} \frac{L_{r i t}}{\bar{L}_{r t}} \ln \left[\frac{L_{r i t}}{\bar{L}_{r t}}\right]$

where: $\mathrm{N}_{r}$ is the total number of industries in the region, and $\bar{L}_{r t}$ is the average employment over $\mathrm{N}$ sectors in the region. The measure of diversification, ranging within the interval $[0,1]$, can be defined as follows:

$D_{3}=\left[1-\left(\frac{T_{r}}{\ln N}\right)\right]$

A higher value of this index is associated with a higher degree of diversification.

In this study we use two of the most commonly used competition measures in the literature. The first measure shows competition between the industries within the same region, and the second is a proxy for the local competition between firms of the same industry. The first measure is defined as follows:

$C_{1}=\frac{H H I_{\text {rit }}}{N_{\text {rit }}}=\sum_{i=1}^{N} \frac{\left(L_{\text {rit }}\right)^{2}}{\left(\sum_{i=1}^{N} L_{\text {rit }}\right)^{2} \times N_{\text {rit }}}$

where definitions of $\mathrm{N}, \mathrm{L}, \mathrm{r}, \mathrm{i}$, and $\mathrm{t}$ are the same as before. Since a larger number of industries $(\mathrm{N})$ can increase the level of competition, and a lower value of the $\mathrm{HHI}$ means the even distribution of industrial activities in the region, a lower value of $\mathrm{C}_{1}$ shows a higher degree of competition in the region.

The second measure captures competition within the local industry relative to overall competition of the industry within all regions. This famous measure of competition has been used by many authors, inter alia, Glaeser et al. (1992). This measure is defined as follows:

$C_{2}=\frac{\left[\frac{I_{\text {rit }}}{L_{r i t}}\right]}{\left[\frac{\sum_{r=1}^{R} I_{r i t}}{\sum_{r=1}^{R} L_{r i t}}\right]}$

where: $I_{\text {rit }}$ is the number of firms in the industry $i$ and in region $r$ at time $t$ and definitions of $\mathrm{R}$ and $\mathrm{L}$ are the same as before. A higher value of this index means that the industry in this region is locally more competitive than it is elsewhere.

Equation (9) derived from the theory can be converted into our estimating equation in the following dynamic panel setup:

$L_{\text {rit }}=\gamma+\sum_{\tau=1}^{T} \rho_{\tau} L_{\text {rit- } \tau}+\sum_{\tau=0}^{T} \theta_{\tau} X_{\text {rit }-\tau}+\delta_{r i}+D_{t}+\varepsilon_{\text {rit }}$

where $L_{\text {rit }}$ is the log of local employment of industry $i(i=1, \ldots, N)$ in region $r(r=1, \ldots, R)$ at time $t(t=1, \ldots, T), \gamma$ is the constant term, and

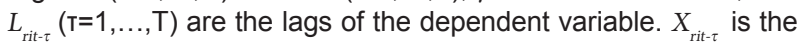
vector of current or lagged explanatory variables, $\delta_{\text {rit }}$ represents the invariant region and industry fixed effects, $D$ indicates time fixed effects, and $\varepsilon_{r, i, t}$ is the vector of error terms. 
The appropriate estimation technique for these types of models is the GMM. We estimated our model using the xtabond2 command by Roodman (2006) in Stata. In line with this estimation technique, the first differences are taken to eliminate the time invariant effects $\delta_{r, i}$; thus, the estimated model will be as follows:

$\Delta L_{\text {rit }}=\sum_{\tau=1}^{T} \rho_{\tau} \Delta L_{r i t-\tau}+\sum_{\tau=0}^{T} \theta_{\tau} \Delta X_{\text {rit- } \tau}+\Delta d_{t}+\Delta \varepsilon_{\text {rit }}$

where: $\Delta L_{r, i, t-\tau}=L_{r, j, t-\tau}-L_{r, i, t-\tau-1}$, and because of using the logarithmic form of the variable, we have the growth rate of the dependent variable on the left hand side of the equation.

All externality indices are in levels, wages are in logarithmic forms, and assuming that they are strictly exogenous, while employment is in logs and endogenous. The first difference of the lagged dependent variable is predetermined and it is instrumented using its higher order time lags in levels. ${ }^{1}$

The impacts of various externalities on employment growth in the high-tech industries will be investigated using European regional structural business statistics at the NUTS-02 regional level during the period 1995-2007. The data was obtained from the Eurostat statistic database website. ${ }^{2}$ The choice of the period was determined by data availability. ${ }^{3}$

Our dataset consists of 3 high-tech industries classified according to the 2-digit level NACE rev1.1 classification. ${ }^{4}$ The industries include manufacture of office machinery and computers (DL30), manufacture of radio, television and communication equipment and apparatus (DL32), and manufacture of medical, precision, and optical instruments, watches and clocks (DL33). Since high-tech industries are relatively research and development intensive, and they are more involved in the process of innovation than other industries, it is expected that knowledge spillovers may be of particular importance in these industries.

\section{Estimation Results}

Table 1 shows the estimation results for three high-tech manufacturing industries in the EEA. Orders of lags are determined in response to the best diagnostics statistics of the regression. We have also added time dummies for each year to control for business cycle and policy changes and improve estimation results. In all estimations, the validity of instruments is verified by the Hansen test for over-identification of restrictions at conventional levels of significance. The baseline estimation results obtained for the measure of diversification $D_{1}$ are reported in column (1), while the sensitivity tests based on alternative measures of diversification $D_{2}$ and $D_{3}$ are reported in columns (2) and (3).

In all the estimated specifications the coefficients on wages are statistically not significant, while the first lag of employment shows the mean reversion of employment growth. Moreover, in all models, nationwide relative concentration does not seem to have a statistically significant impact on the regional employment growth in high-tech manufacturing industries. This result is in line with the results reported in the previous empirical studies, such

\footnotetext{
${ }^{1}$ Including logarithmic forms of spillover measures makes little change to the significance of coefficients.

${ }^{2}$ Eurostat Statistical Database: http://epp.eurostat.ec.europa.eu/portal/page/portal/ statistics/search_database

${ }^{3}$ It is not possible to include more recent years due to a change in the NACE classification.

${ }^{4}$ According to the industrial codes of NACE Rev. 1.1, Eurostat 2009 and OECD 2011 classified manufacturing industries at 2-digit level in four subgroups of high-technology, medium high-technology, medium low-technology, and low-technology, based on the technology intensity and level of R\&D used in these industries.
}

as Glaeser et al. (1992), which used this measure of concentration to find relatively insignificant impacts of specialization on growth. Therefore, we can argue that on the basis of the use of the measure of nationwide relative concentration it is not possible to confirm the existence of the MAR externalities in the high-tech manufacturing industries.

Moreover, we do not find the importance of Jacobs externalities related to urban diversity, as none of the estimated coefficients on diversification measures that we used appear statistically significant in any of the estimated specifications. We also did not find robust evidence for the impact of the measure of competition between industries $\left(C_{1}\right)$ on employment growth, as the estimated coefficient on this measure was statistically significant only at the 10 per cent level and only in one of the estimated specifications reported in column (3). In all other specification the estimated coefficient on this measure was not statistically significant at any of the usually accepted levels of statistical significance.

The only robust evidence we found was for the measure of local competition between firms within the industry $\left(C_{2}\right)$, which was statistically significant in all the estimated specifications at either 1 or 5 per cent levels of statistical significance. This result is in line with the results of previous empirical studies showing that more intense local competition is strongly related to decreasing employment growth. Imitation of innovations by other firms in the region can damage the profitability of firms investing in R\&D and result in a less innovative environment.

Inefficient protection of intellectual property rights in a competitive regional industry can increase the diffusion of knowledge across firms in a very short period of time. Despite patent registrations, a very competitive operating environment might discourage firms from employing innovative strategies, as their innovative processes can be diffused by other economic agents within close proximity before they can profit from their innovations. On the other hand, in an industry with a more monopolistic structure, firms are innovating in a more secure environment, in which a leak in the innovative process can no longer be transferred by economic agents. Firms that are situated in more distant locations cannot easily and quickly receive information on other firms' innovation procedures. In fact, the leakage of innovative processes to other regions can occur only after the availability of product or patent registrations, which are already a safeguard against imitation. Overall, it is quite reasonable to argue, in line with the MAR hypothesis, that a more monopolistic structure of an industry in a given region can enhance firms' growth by protecting their innovative processes. Therefore, a more efficient framework to protect the intellectual property rights of firms can assist employment growth induced by innovations.

\section{Conclusions}

This paper studied the impact of externalities associated with knowledge spillovers and the market structure on regional employment growth in the EEA. The analysis covered 3 hightech industries at NACE rev. 1.1 2-digit levels in 285 NUTS-2 regions during the period 1995-2007. It was shown that neither nation-wide specialization nor diversification is related to regional employment growth. This result does not seem to support the existence of any agglomeration externalities. However, it was shown that there is strong robust evidence that local competition between firms is negatively related to employment growth in these industries. This result clearly contradicts the Jacobs-Porter hypothesis on the positive impact of increased competition on employment growth. Instead, monopoly can provide an opportunity for firms to internalize the externalities, in order to 
MISCELLANEA GEOGRAPHICA - REGIONAL STUDIES ON DEVELOPMENT

Vol. 19 • No. 3 - 2015 • pp. 76-81 • ISSN: 2084-6118 • DOI: 10.1515/mgrsd-2015-0007

Table 1. Estimation results for three high-tech manufacturing industries in the EEA (1995-2007)

\begin{tabular}{|c|c|c|c|c|}
\hline \multirow{2}{*}{\multicolumn{2}{|c|}{$\begin{array}{l}\text { Dependent Variable: Regional employment of the } \\
\text { industry } \\
\text { (1) }\end{array}$}} & \multicolumn{3}{|c|}{ Specifications } \\
\hline & & (2) & (3) & \\
\hline \multicolumn{2}{|l|}{ No. of Obs. } & 2695 & 2695 & 2695 \\
\hline \multicolumn{2}{|l|}{ No. of Groups } & 536 & 536 & 536 \\
\hline \multicolumn{2}{|l|}{ Time Dummies } & Yes & Yes & Yes \\
\hline \multirow[t]{3}{*}{$\log \mathrm{L}_{r}$} & $\mathrm{t}-1$ & $\begin{array}{c}0.838^{* * *} \\
(0.097)\end{array}$ & $\begin{array}{c}0.862^{* * *} \\
(0.094)\end{array}$ & $\begin{array}{c}0.736^{* * *} \\
(0.131)\end{array}$ \\
\hline & $\mathrm{t}-2$ & $\begin{array}{c}0.065 \\
(0.092)\end{array}$ & $\begin{array}{c}0.051 \\
(0.092)\end{array}$ & $\begin{array}{c}0.142 \\
(0.124)\end{array}$ \\
\hline & $\mathrm{t}-3$ & $\begin{array}{c}0.025 \\
(0.029)\end{array}$ & $\begin{array}{c}0.030 \\
(0.027)\end{array}$ & $\begin{array}{c}0.022 \\
(0.026)\end{array}$ \\
\hline \multirow[t]{3}{*}{$\log W_{r, i}$} & $\mathrm{t}$ & $\begin{array}{c}0.009 \\
(0.021)\end{array}$ & $\begin{array}{c}0.015 \\
(0.021)\end{array}$ & $\begin{array}{c}0.011 \\
(0.019)\end{array}$ \\
\hline & $\mathrm{t}-1$ & $\begin{array}{c}-0.018 \\
(0.023)\end{array}$ & $\begin{array}{l}-0.016 \\
(0.024)\end{array}$ & $\begin{array}{l}-0.023 \\
(0.022)\end{array}$ \\
\hline & $\mathrm{t}-2$ & $\begin{array}{c}0.033 \\
(0.031)\end{array}$ & $\begin{array}{c}0.034 \\
(0.031)\end{array}$ & $\begin{array}{c}0.027 \\
(0.029)\end{array}$ \\
\hline \multirow[t]{3}{*}{ Nationwide relative concentration (S) } & $\mathrm{t}$ & $\begin{array}{c}0.004 \\
(0.028)\end{array}$ & $\begin{array}{c}0.003 \\
(0.029)\end{array}$ & $\begin{array}{c}-0.013 \\
(0.026)\end{array}$ \\
\hline & $\mathrm{t}-1$ & $\begin{array}{c}-0.00004 \\
(0.017)\end{array}$ & $\begin{array}{c}0.002 \\
(0.017)\end{array}$ & $\begin{array}{c}0.009 \\
(0.021)\end{array}$ \\
\hline & $\mathrm{t}-2$ & $\begin{array}{c}-0.017 \\
(0.031)\end{array}$ & $\begin{array}{c}-0.011 \\
(0.035)\end{array}$ & $\begin{array}{l}-0.027 \\
(0.043)\end{array}$ \\
\hline \multicolumn{2}{|l|}{ Diversification Indices } & $\mathrm{D}_{1}$ & $\mathrm{D}_{2}$ & $\mathrm{D}_{3}$ \\
\hline & $\mathrm{t}$ & $\begin{array}{l}-1.01 \\
(4.84)\end{array}$ & $\begin{array}{c}0.032 \\
(0.335)\end{array}$ & $\begin{array}{c}2.31 \\
(1.97)\end{array}$ \\
\hline & $\mathrm{t}-1$ & $\begin{array}{c}-5.13 \\
(5.299)\end{array}$ & $\begin{array}{c}0.134 \\
(0.357)\end{array}$ & $\begin{array}{l}0.563 \\
(2.29)\end{array}$ \\
\hline & $\mathrm{t}-2$ & $\begin{array}{l}-1.47 \\
(4.63) \\
\end{array}$ & $\begin{array}{l}-0.024 \\
(0.313) \\
\end{array}$ & $\begin{array}{c}0.65 \\
(1.57) \\
\end{array}$ \\
\hline \multirow[t]{3}{*}{ Inter-industrial competition $\left(\mathrm{C}_{1}\right)$} & $\mathrm{t}$ & $\begin{array}{l}64.03 \\
(92.6)\end{array}$ & $\begin{array}{l}43.04 \\
(52.9)\end{array}$ & $\begin{array}{l}99.2^{*} \\
(57.2)\end{array}$ \\
\hline & $\mathrm{t}-1$ & $\begin{array}{l}108.07 \\
(93.3)\end{array}$ & $\begin{array}{l}43.003 \\
(50.7)\end{array}$ & $\begin{array}{c}36.5 \\
(44.3)\end{array}$ \\
\hline & $\mathrm{t}-2$ & $\begin{array}{l}-31.8 \\
(71.8)\end{array}$ & $\begin{array}{l}-41.2 \\
(34.6)\end{array}$ & $\begin{array}{l}-58.1 \\
(37.8)\end{array}$ \\
\hline \multirow[t]{3}{*}{ Local competition between firms $\left(\mathrm{C}_{2}\right)$} & $\mathrm{t}$ & $\begin{array}{c}-0.17^{* * *} \\
(0.063)\end{array}$ & $\begin{array}{c}-0.154^{* *} \\
(0.061)\end{array}$ & $\begin{array}{c}-0.2003^{* * *} \\
(0.074)\end{array}$ \\
\hline & $\mathrm{t}-1$ & $\begin{array}{c}0.117^{\star * *} \\
(0.041)\end{array}$ & $\begin{array}{c}0.125^{\star * *} \\
(0.045)\end{array}$ & $\begin{array}{l}0.091^{* *} \\
(0.039)\end{array}$ \\
\hline & $\mathrm{t}-2$ & $\begin{array}{c}0.014 \\
(0.024)\end{array}$ & $\begin{array}{c}0.011 \\
(0.023)\end{array}$ & $\begin{array}{c}0.03 \\
(0.034)\end{array}$ \\
\hline \multicolumn{2}{|c|}{ Sargan test of overid. restrictions; Prob $>$ chi2 $=$} & 0.217 & 0.046 & 0.076 \\
\hline \multicolumn{2}{|c|}{ Hansen test of overid. restrictions; Prob > chi2 = } & 0.182 & 0.055 & 0.078 \\
\hline \multicolumn{2}{|c|}{ Iv, Difference (null H = exogenous); Prob > chi2 = } & 0.116 & 0.010 & 0.044 \\
\hline \multicolumn{2}{|c|}{$A B$ test for $A R(1)$ in first differences: $P>Z=$} & 0.000 & 0.000 & 0.001 \\
\hline \multicolumn{2}{|c|}{$A B$ test for $A R(2)$ in first differences: $P>z=$} & 0.658 & 0.785 & 0.498 \\
\hline
\end{tabular}

Source: Own estimation using Stata; ${ }^{* *}$-significant at $1 \%$ level; ${ }^{* *}$-significant at $5 \%$ level; ${ }^{*}$-significant at $10 \%$ level; robust corrected standard errors in parentheses. 
reap higher profits from their innovations. Therefore, in line with the MAR hypothesis, a more monopolistic market structure of a particular industry in a given region can provide a more secure environment for a firm to innovate. Hence, as monopoly enhances the growth of high-technology industries in the EEA, more effective and efficient protection of intellectual property rights is necessary to reduce the imitation of innovation by competitors in the regions where knowledge spillovers may occur very quickly.

\section{References}

Arellano, M, \& Bond, SR 1991. 'Some tests of specification for panel data: Monte Carlo evidence and an application to employment equations', Review of Economic Studies, vol. 58, pp. 227-297.

Arrow, K, 1962. 'The economic implications of learning by doing', Review of Economic Studies, vol. 29, pp. 155-172.

Blien, U, Suedekum, J \& Wolf, K 2006. 'Local employment growth in West Germany: A dynamic panel approach', Labour Economics, vol. 13, pp. 445-458.

Cieślik, A, \& Ghodsi, MM 2014. 'Regional knowledge spillovers in the European Economic Area: The case of three high-tech industries,' Ekonomia, vol. 36, pp. 23-49.

Combes, PP 2000. 'Economic structure and local growth: France 1984-1993', Journal of Urban Economics, vol. 47, pp. 329355.

Duranton, G \& Puga, D 2000. 'Diversity and specialisation in cities why, where and when does it matter?', Urban studies, vol. 37, pp. 533-555.

Eurostat Statistical Database 2014, Search database. Available from: <http://epp.eurostat.ec.europa.eu/portal/page/portal/ statistics/search_database>.

Eurostat. Eurostat yearbook. 2009. Europe in figures. ISSN 1681-4789.

Glaeser, EL, Kallal, HD \& Scheinkman, JA 1992. 'Growth in Cities', The Journal of Political Economy, vol. 100, pp. 1126-1152.
Greunz, L 2004. 'Industrial structure and innovation - evidence from European regions', Journal of Evolutionary Economics, vol. 14, pp. 563-92.

Henderson, V, Kuncoro, A \& Turner, M 1995. 'Industrial development in cities', Journal of Political Economy, vol. 103, pp. 1067-1085.

Jacobs, J 1969. The Economies of Cities. Random House, New York.

Lucas, RJr, 1988. 'On the mechanics of economic development', Journal of Monetary Economics, vol. 22, pp. 3-42.

Marshall, A 1890. Principles of Economics. MacMillan, London.

NACE - Classification of Economic Activities in the European Community.

OECD, OECD Directorate for Science, Technology and Industry. 2011. ISIC Rev. 3 Technology Intensity Definition, Classification of manufacturing industries into categories based on R\&D intensities. OECD Publishing.

Porter, M 1990. The Competitive Advantage of Nations. Macmillan, London.

Romer, PM 1986. 'Increasing returns and long-run growth', Journal of Political Economy, vol. 94, pp. 1002-1037.

Roodman, D (2006). How to do xtabond2: An introduction to difference and system GMM in Stata. Center for Global Development working paper, (103).

Theil, H 1967. Economics and Information Theory. Amsterdam: North Holland. 